\title{
MANURE TEA AND AMINO ACIDS AS POTENTIAL ECONOMIC AND SAFE SUBSTITUTES FOR MINERAL AND ORGANIC FERTILIZATION AND THE EFFECT ON GROWTH, YIELD AND CHEMICAL COMPOSITION OF FABA BEAN PLANTS.
}

Mahmoud, M. M.

Soils, Water \& Environ. Res. Inst., Agric.Res.Center, Giza, Egypt.

\begin{abstract}
A field experiment was conducted on a calcareous soil at Abou massoud village (48 km south-west to Alexandria) to study the possibility of partial substitution of NPK fertilizer and/or chicken manure by foliar spray of manure tea or amino acids and their effect on soil organic matter and available macronutrients in soil as well as vegetative characters, photosynthetic pigments, macronutrients and protein content and faba bean yield and its components.

Treatments included mineral fertilizers (MF) at the rate of 35,65 and $100 \%$ of the recommended dose of $\mathrm{N}, \mathrm{P}$ and $\mathrm{K}(\mathrm{RDF})$ and chicken manure $(\mathrm{CM})$ at the rate of 1 ton/fed $\left(\mathrm{CM}_{1}\right)$ and 2 ton/fed $\left(\mathrm{CM}_{2}\right)$ along with foliar spray by manure tea or amino acids $(1000 \mathrm{mg} / \mathrm{l})$.

Results indicated that soil organic matter content significantly increased due to the application of the two rates of chicken manure. Available N, P and $\mathrm{K}$ in soil showed pronounced increase upon the application of MF and/or CM with a superiority for the treatment of $100 \% \mathrm{RDF}+\mathrm{CM}_{2}$ over the other treatments. Vegetative growth characters, photosynthetic pigments, N, P, K and protein content in seeds as well as seed yield and yield components progressively increased with increasing the applied rates of MF and/or CM up to $100 \%$ RDF and CM2 and the increase was more prominent under the mixture application of both types of fertilizers. Moreover, all the aforementioned parameters were highly significantly enhanced with the foliar spray of manure tea or amino acids. Treatments fertilized with MF and CM and sprayed with manure tea or amino acids simultaneously gave additional promoting effects on the above mentioned parameters compared to the treatments receiving the sole or mixture application of MF and CM. In spite of the treatment of full dose of NPK along with $\mathrm{CM}_{1}+$ manure tea or amino acids produced the highest faba bean yield (1350 $\mathrm{kg} / \mathrm{fed}$ ), the yield obtained by the treatment of $65 \%$ NPK with manure tea (1164 $\mathrm{kg} / \mathrm{fed}$ ) or amino acids (1172 kg/fed) was higher than the yield recorded by the single application of $100 \%$ RDF (1110 kg/fed), indication that the need for NPK fertilizers could be reduced to $65 \%$ compared to $100 \%$ RDF and saving $35 \%$ NPK fertilizers.

Keywords: Amino acids, chicken manure, faba bean, manure tea, NPK fertilizers.
\end{abstract}

\section{ITRODUCTION}

Faba bean (vicia faba L.) is one of the most important winter leguminous crops grown in different types of Egyptian soils. Furthermore,, faba been is considered as one of the basic sources of plant protein for human consumption especially in Egypt.

In many regions, researches recently shifted to utilization of organic materials as nutrient source in crop production. Excessive use of chemical fertilizers deteriorates soil structure, pollutes ground water and increase 
nitrate concentration in vegetables (Zhang et al ., 2010). Although, the use of mineral fertilizers cannot be overlooked; however, due to their rising costs and environmental and health concerns, there is need to supplement or substitute them with available organic sources (Chaudhry et al., 2009). Therefore, integrated nutrient management including application of organic manures and organic compounds (such as humic and amino acids or compost and manure tea) is practiced to enhance soil fertility and sustain crop production.

Chicken manure has been recognized as valuable source of plant nutrients for crops, and preferred amongst other animal wastes because its high concentration of macronutrients (Duncan, 2005). Alarg portion of the $\mathrm{N}$ in poultry manure is in organic fraction, but 20 to $40 \%$ of the total $\mathrm{N}$ is inorganic (Willrich et al., 1974). Sharma and Rao (1996) reported that poultry manure is a good source of nutrients and it also improves the physical properties of the soil. Addition of chicken manure (up to 6 ton ha ${ }^{-1}$ ) with 0 , 25,50 and $100 \%$ recommended dose of fertilizer (RDF) increased rice yield, $\mathrm{N}, \mathrm{P}$ and $\mathrm{K}$ uptake as well as available $\mathrm{N}, \mathrm{P}$ and $\mathrm{K}$ in soil (Suvarnalatha,2001). Integrated use of fertilizers and poultry manure exhibited additive effect on groundnut pod yield in the treatment receiving full recommended dose of inorganic fertilizer along with poultry manure at rate of 3 ton/ha (Talashilkar et al., 1997). Application of poultry manure at 5 ton/ha had significant beneficial effect on rice seed yield and improve the soil NPK status if applied continuously. However, based on cost consideration, applications of poultry manure at 2 ton/ha and $75 \%$ recommended NPK was found economical (Chettri and Bandhopadhaya, 2005).

Compost tea is one of the most promise bio-fertilizer recently responsible for developing different management controlling programs e.g. plant disease and fertility (Sheuerell and Mahaffee, 2002). The concept of compost or manure tea is becoming increasingly popular in organic agriculture. Compost and manure tea are simply liquid extracts made by soaking bags of various kinds of compost or organic manure in water to create a liquid rich in the beneficial nutrients, organic compounds and microbes. The liquid tea is applied in fertigation systems or as foliar spray. The concept of compost tea is relatively new and there are very few research reports documenting its effectiveness. Research has documented that compost teas suppress diseases in organic systems (Haggag and saber, 2007). Other benefits of compost tea are the stimulation of root and vegetative growth (Hibar et al., 2006). Compost tea has been also found to increase crop yield of tomato and onion. Significant improvements in three faba bean cultivars were obtained due to foliar spraying of compost tea. Total chlorophyll, $\mathrm{N}$ and $\mathrm{P}$ content in seeds and faba bean yield were significantly increased as a result of foliar spraying with compost tea (Ghobrial et al., 2009). In a field experiment on kidney bean treated with compost tea and humic acid under different rates of nitrogen fertilizer and compost, the superior treatment was when compost extract was sprayed alternatively with humic in present of $75 \%$ of mineral nitrogen with 10 ton/fed of compost as soil addition (Meshref et al., 2010). 
Amino acids are fundamental ingredients in the process of protein synthesis. About 20 important amino acids are involved in the process of each function. Amino acids can directly or indirectly influence the physiological activities of the plant. Functionally, amino acids are involved in the enzymes responsible for the structural photosynthesis process. Further, amino acids have a chelating effect on micronutrients. When applied together with micronutrients, the absorption and transportation of micronutrients inside the plant is easier (Ibrahim et al.,2007). The application of amino acids for foliar use is based on its requirement by plant in general and at critical stages of growth in particular. Plants absorb amino acids through stomas and is proportionate to environment temperature that controls the opening mechanism of the plant stomas. Amino acids have a good mobility and tendency to be transported in plants. Many vital plant mechanisms are stimulated after application of amino acids, this fact characterizes amino acids as a real biostimulants able to equilibrate the nutritional functions. Plants can take up nitrogen in forms of amino acids without relying on microbial mineralization (Lipson and Nasholm, 2001). Foliar application of amino acids stimulate growth, yield and chemical composition of faba bean (El-Ghamry et al., 2009), snap bean (Fawzy et al., 2010), peanut and sesame (Eisa,Salwa,2011).

The objective of this work was to evaluate the potential use of amino acids and manure tea in integrated fertilization management for enhancing growth, yield and chemical composition of faba bean plants.

\section{MATERIALS AND METHODS}

A field experiment was conducted during the winter season of 2008/2009 on a calcareous soil located at Abou Masooud farm (48 Km southwest to Alexandria), Alexandria Governorate, Egypt. The initial physical and chemical properties of the studied soil are presented in Table (1).

Faba been seeds (vicia faba L.,c.v. Nobareya 1) were sown in plots with $10.5 \mathrm{~m}^{2}$ in area $(3 \times 3.5 \mathrm{~m})$. The experiment was designed in a split plot design with three replicates. The treatments included three levels of mineral fertilizers, i.e. 35,65 and $100 \%$ of the recommended dose of N, P and K [ $100 \mathrm{~kg}$ ammonium sulphate $(20.5 \% \mathrm{~N}), 200 \mathrm{~kg}$ superphosphate $\left(15 \% \mathrm{P}_{2} \mathrm{O}_{4}\right)$ and $100 \mathrm{~kg}$ potassium sulphate $\left(48 \% \mathrm{~K}_{2} \mathrm{O}\right)$ ]. While organic material comprises the following treatments:

1- Control ( without organic materials)

2- Chicken manure at rate of 1 ton/fed $\left(\mathrm{CM}_{1}\right)$

3- Chicken manure at rate of 2 ton/fed $\left(\mathrm{CM}_{2}\right)$

4- Manure tea

5- Amino acids at rate of $1000 \mathrm{mg} / \mathrm{L}$

6- Manure tea $+\mathrm{CM}_{1}$

7- Amino acids $+\mathrm{CM}_{1}$

Manure tea and amino acids ( $10 \%$ free amino acids $+7 \%$ organic matter $+5 \%$ total $\mathrm{N}$ ) were applied as foliar spray three times after $30,45 \mathrm{ad}$ 60 days from sowing. All the agricultural recommended practices were followed as usual including the irrigation processes. 
Table (1): Some physical and chemical properties of the soil under investigation.

\begin{tabular}{|c|c|c|}
\hline $\begin{array}{l}\text { Particle size distribution it } \\
\text { presence of } \mathrm{CaCO}_{3} \text { : }\end{array}$ & $(d S / m)$ & 2.28 \\
\hline $\begin{array}{lll}\text { Clay } & (\%) & 15.2 \\
\end{array}$ & Cations meq/L : & \\
\hline$(\%)$ & $\mathrm{Ca}^{2+}$ & 768 \\
\hline Fine sand $(\%)$ & $\mathrm{Mg}^{2+}$ & 4.62 \\
\hline Coarse sand ( \%) & $\mathrm{Na}^{+}$ & 10.1 \\
\hline Textural class : Sandy clay loam & & 0.70 \\
\hline $\mathrm{CaCO}_{3}$ & Anions meq/L : & \\
\hline O.M. & $\mathrm{CO}_{3}{ }^{2-}$ & 0.00 \\
\hline $\mathrm{pH}(1-2.5$ susp.) & $\mathrm{HCO}_{3}{ }^{\circ}$ & 5.57 \\
\hline Available macronutrients & $\mathrm{Cl}^{-}$ & 7.03 \\
\hline Available $\mathrm{N}$ mg/kg soil & $\mathrm{SO}_{4}^{2-}$ & 10.5 \\
\hline $\begin{array}{l}\text { Available P mg/kg soil } \\
\text { Available K mg/kg soil }\end{array}$ & & \\
\hline
\end{tabular}

Table (2): Some chemical properties of chicken manure and manure tea.

\begin{tabular}{|l|c|c|c|c|c|c|}
\hline \multicolumn{1}{|c|}{ Character } & pH & $\begin{array}{c}\text { O.C } \\
\%\end{array}$ & $\begin{array}{c}\text { Total } \\
\text { N\% }\end{array}$ & C/N ratio & Total P\% & Total K\% \\
\hline Chicken manure & 7.75 & 26.1 & 2.24 & 11.7 & 1.12 & 1.83 \\
\hline Manure tea & 7.10 & 7.40 & 0.86 & 8.60 & 0.70 & 1.16 \\
\hline
\end{tabular}

\section{Preparation of chicken manure tea:}

To make chicken manure tea, we put the chicken manure in a sack made from a burlap or other porous cloth that will act as a strainer to separate the solid from the liquid and immersed the sack in a barrel full of water (The quantity of the manure fill $1 / 3$ of the barrel's size ), the manure left in water for 7 days to ferment and allow nutrients to dissolve. For foliar spraying, the brew was diluted ten times and should look the colour of weak tea, and regular applied every 15 days during the vegetative stage. At the flowering stage, foliar was stopped to avoid falling of the flowers.

\section{Photosynthetic pigments:}

Photosynthetic pigments (chlorophyll a, b and carotenoids) were extracted from the fourth upper leaves at 70 days age using acetone $85 \%$ and determined calorimetrically according to the method described by Wettestein (1957).

Yield and its components:

At harvest (150 days after sowing), number of pods/plant, 100 seeds weight $(\mathrm{g})$ and seed yield $(\mathrm{kg} / \mathrm{fed})$ were recorded. Samples of faba bean seeds were digested using $\mathrm{H}_{2} \mathrm{SO}_{4}$ and $\mathrm{H}_{2} \mathrm{O}_{2}$. Total nitrogen was determined 
using the standard procedure of micro-kjeldahl as described by black (1965). Total phosphorus and potassium were determined according to Jackson (1973).

Soil analysis:

Soil samples were collected from all experimental plots after 70 days from sowing. Organic matter content was determined by the Walkey and Black method (Black, 1965). Available N, P and K in soil were determined according to Jackson (1973).

\section{Statistical analysis:}

All obtained data were statistically analyzed and compared by using least significant differences (L.S.D) according to the procedure described by Gomez and Gomez (1984).

\section{RESULTS AND DISCUSSION}

\section{Organic matter content and available $N, P$ and $K$ in soil:}

Organic matter content in soil as affected by different treatments is presented in Table (3), data showed marked increases in organic matter content by the addition of chicken manure particularly with the second rate $\left(\mathrm{CM}_{2}\right)$. Increases due to $\mathrm{CM}_{1}$ and $\mathrm{CM}_{2}$ averaged 11.8 and $21.6 \%$ respectively. Otherwise, no significant changes were occurred in organic matter content upon the solely application of mineral fertilizers and/or foliar spray of amino acids and manure tea. Ayeni and Adetunji (2010) confirmed these findings.

Considering available $\mathrm{N}, \mathrm{P}$ and $\mathrm{K}$ in soil, results indicated that available, $\mathrm{N}, \mathrm{P}$ and $\mathrm{K}$ significantly increased upon mineral fertilizers application, and the increase was progressive up to the rate of $100 \%$ of the recommended dose of fertilizers (RDF).

As opposed to use the sole application of NPK fertilizers, the combined use of chicken manure ensured more availability of N, P and K. The highest values of available N,P and K (93.5, 16.1 and $398 \mathrm{mg} / \mathrm{kg}$ soil, respectively) were recorded under the treatment of $\mathrm{CM}_{2}$ ( 2 ton chicken manure/fed) along with $100 \%$ RDF. Beside the relatively high-N, P and $\mathrm{K}$ content in chicken manure and the more balanced nutrition given by chicken manure (Ayeni and Adetunji, 2010), the effect of organic manure in improving the moisture retention by soil could have enhanced the retentive capacity for available nutrients. Moreover, the additions of organic manure also enhance the soil microbial activity (El-Ghamry, 2011) which in turn works to convert the organic form to mineral form. 
Mahmoud, M. M.

3

1064 


\section{Vegetative growth characters:}

Data presented in Table (4) indicated that plant height, number of branches and dry weight of shoot were considerably augmented due to the single or mixture application of mineral fertilizers and chicken manure and the increases progressed with increasing their rates up to $100 \%$ RDF and /or 2 ton chicken manure/fed $\left(\mathrm{CM}_{2}\right)$. Incorporated mineral fertilizers with chicken manure resulted in higher values of the aforementioned parameters compared to those values obtained when they added separately. In this respect, values of the relative increases of plant height, number of branches and dry weight of shoot due to the treatment of $100 \% \mathrm{RDF}+\mathrm{CM}_{2}$ were 34.4, 57.5 and $34.4 \%$ over the control. Similar results were obtained by Meshref et al. (2010) on kidney bean and Gomaa et al. (2010) on faba bean.

Concerning foliar application of manure tea or amino acids, results showed that foliar spray of both manure tea or amino acids significantly stimulated plant height, number of branches and dry weight of shoot and such positive effect holds true under the different rates of mineral fertilizers or chicken manure. The obtained values following the application of manure tea and amino acids (regardless of mineral or organic fertilizers) did not differ significantly in their effects on growth parameters. Despite the treatment of full dose of NPK with $\mathrm{CM}_{1}+$ manure tea or amino acids gave the highest growth parameters, the application of $65 \% \mathrm{NPK}$ along with $\mathrm{CM}_{1}$ and manure tea or amino acids overcome the treatments receiving the sole application of $100 \%$ NPK, indicating that the need for NPK fertilizers can be reduced to 65 $\%$ RDF as opposed to $100 \%$ RDF. These results agree with those of Meshref et al. (2010) who found that spraying kidney bean with compost tea led to significant increases in plant height and dry weight of shoot and ascribed that to its remarkable nutritional values that are present in soluble chemical components into an aqueous sphere.

Table (4): Effect of chicken manure, manure tea, amino acids and NPK fertilizers on the growth characters of faba bean at 90 days age.

\begin{tabular}{|c|c|c|c|c|c|c|c|c|c|c|c|c|}
\hline \multirow{3}{*}{\begin{tabular}{|l} 
\\
Treatments \\
(B)
\end{tabular}} & \multicolumn{12}{|c|}{ (A) Fertilizer levels (\% recommended dose of NPK) } \\
\hline & \multicolumn{4}{|c|}{ Plant height (cm) } & \multicolumn{4}{|c|}{ No. of branches } & \multicolumn{4}{|c|}{$\begin{array}{c}\text { Dry weight of shoot } \\
\text { (g/plant) }\end{array}$} \\
\hline & 35 & 65 & 100 & Mean & 35 & 65 & 100 & Mean & 35 & 65 & 100 & Mean \\
\hline Control & 52.1 & 59.0 & 63.5 & 58.2 & 2.33 & 2.67 & 3.00 & 2.67 & 67.2 & 75.6 & 79.0 & 73.9 \\
\hline $\mathrm{CM}_{1}$ & 58.4 & 63.1 & 66.8 & 62.8 & 3.00 & 3.33 & 3.33 & 3.22 & 72.8 & 80.0 & 85.9 & 79.6 \\
\hline $\mathrm{CM}_{2}$ & 63.8 & 66.8 & 70.0 & 66.9 & 3.33 & 3.67 & 3.67 & 3.56 & 77.4 & 85.4 & 90.3 & 84.4 \\
\hline Manure tea & 62.0 & 65.2 & 68.4 & 65.2 & 3.33 & 3.33 & 3.67 & 3.44 & 76.0 & 83.8 & 88.7 & 82.8 \\
\hline Amino acids & 62.4 & 66.0 & 68.8 & 65.7 & 3.33 & 3.33 & 3.67 & 3.44 & 76.7 & 84.1 & 89.0 & 83.3 \\
\hline \multirow{2}{*}{\begin{tabular}{|l} 
anure tea $+\mathrm{CM}_{1}$ \\
mino acids $+\mathrm{CM}_{1}$
\end{tabular}} & 65.3 & 69.4 & 73.0 & 69.2 & 3.67 & 4.00 & 4.00 & 3.89 & 84.5 & 90.0 & 93.6 & 89.4 \\
\hline & 68.2 & 71.5 & 75.1 & 71.6 & 3.67 & 4.00 & 4.00 & 3.89 & 88.0 & 93.2 & 96.5 & 92.6 \\
\hline Mean & 61.7 & 65.9 & 69.4 & & 3.24 & 3.48 & 3.62 & & 77.5 & 84.6 & 89.0 & \\
\hline \multirow{3}{*}{\begin{tabular}{|l||l|} 
LSD $_{0.05}$ & $\mathrm{~B}$ \\
\cline { 2 - 2 } & $\mathrm{AxB}$
\end{tabular}} & \multicolumn{4}{|c|}{3.37} & \multicolumn{4}{|c|}{0.20} & \multicolumn{4}{|c|}{3.90} \\
\hline & \multicolumn{4}{|c|}{3.10} & \multicolumn{4}{|c|}{0.18} & \multicolumn{4}{|c|}{3.65} \\
\hline & \multicolumn{4}{|c|}{6.16} & \multicolumn{4}{|c|}{ N.S } & \multicolumn{4}{|c|}{ N.S } \\
\hline
\end{tabular}

See footnotes of Table 3 for treatment designations. 
The importance of amino acids came from their widely uses for the biosynthesis of a large variety of non-protein nitrogenous materials, i.e. pigments, vitamins, coenzymes, purine and pyrimedine bases (Bidwell, 1980). Amino acids could directly or indirectly influence the physiological activities of plant growth and development, through their regulatory effects on production of gibberellins in plant tissues (Waller and Nowaki, 1978). In this concern, El-Ghamry et al. (2009) reported that foliar application of amino acids at the rate of 1000 or $2000 \mathrm{mg} / \mathrm{l}$ significantly increased plant height as well as number of leaves and branches / plant of faba bean plants.

\section{Photosynthetic pigments in faba bean leaves:}

The content of photosynthetic pigments in faba bean leaves at 70 days age as affected by different treatments is presented in Table (5). Data showed that all photosynthetic pigments (chlorophyll a, b and carotenoids) were significantly increased following the addition of mineral fertilizers and/or chicken manure. The more the rate of NPK fertilizers and/or chicken manure was the more the effect was. The combined application of NPK fertilizers and chicken manure recorded higher values for photosynthetic pigments compared to the sole application of any of the two types of fertilizers. The maximum chlorophyll $\mathrm{a}, \mathrm{b}$ and carotenoids (regardless of manure tea or amino acids) were 2.07, 0.97 and $1.20 \mathrm{mg} / \mathrm{g}$ fresh weight, respectively, and that occurred under the treatment of $100 \% \mathrm{RDF}+\mathrm{CM}_{2}$. These findings are in agreements with those reported by Taiz and Zeiger (1998) who mentioned that chlorophyll content vary according to mineral status ( $N, P$ and $K$ ) of plants. Also, Eid, Rawia et al. (2006) who attributed the increase in chlorophyll content and carotenoids to the increase in $\mathrm{N}$ uptake due to the application of FYM and mineral N.

Table (5): Effect of chicken manure, manure tea, amino acids and NPK fertilizers on photosynthetic pigments ( $\mathrm{mg} / \mathrm{g}$ fresh weight) in faba bean leaves at 70 days age.

\begin{tabular}{|c|c|c|c|c|c|c|c|c|c|c|c|c|}
\hline \multirow{3}{*}{$\begin{array}{l}\text { Treatments } \\
\text { (B) }\end{array}$} & \multicolumn{12}{|c|}{ (A) Fertilizer levels (\% recommended dose of NPK) } \\
\hline & \multicolumn{4}{|c|}{ Chlorophyll (a) } & \multicolumn{4}{|c|}{ Chlorophyll (b) } & \multicolumn{4}{|c|}{ Carotenoids } \\
\hline & 35 & 65 & 100 & Mean & 35 & 65 & 100 & Mean & 35 & 65 & 100 & Mean \\
\hline & 1.46 & 1.70 & 1.84 & 1.67 & 0.65 & 0.79 & 0.90 & 0.78 & 0.82 & 0.97 & 1.09 & 0.96 \\
\hline $\mathrm{CM}_{1}$ & 1.62 & 1.79 & 1.98 & 1.80 & 0.80 & 0.88 & 0.95 & 0.88 & 0.94 & 1.05 & 1.14 & 1.04 \\
\hline $\mathrm{CM}_{2}$ & 1.75 & 1.95 & 2.07 & 1.92 & 0.88 & 0.93 & 0.97 & 0.93 & 1.03 & 1.13 & 1.20 & 1.12 \\
\hline Manure tea & 1.84 & 2.00 & 2.16 & 2.00 & 0.90 & 0.96 & 1.00 & 0.95 & 1.06 & 1.16 & 1.23 & 1.15 \\
\hline Amino acids & 1.90 & 2.10 & 2.25 & 2.08 & 0.92 & 0.98 & 1.02 & 0.97 & 1.08 & 1.16 & 1.25 & 1.16 \\
\hline Manure tea + $\mathrm{CM}_{1}$ & 2.07 & 2.26 & 2.40 & 2.24 & 0.97 & 1.01 & 1.04 & 1.01 & 1.13 & 1.22 & 1.30 & 1.22 \\
\hline Amino acids+ $\mathrm{CM}_{1}$ & 2.20 & 2.38 & 2.51 & 2.36 & 1.00 & 1.05 & 1.09 & 1.05 & 1.17 & 1.27 & 1.34 & 1.26 \\
\hline Mean & 1.83 & 2.03 & 2.17 & & 0.87 & 0.94 & 1.00 & & 1.03 & 1.14 & 1.22 & \\
\hline \multirow{3}{*}{$\operatorname{LSD}_{0.05}$} & \multicolumn{4}{|c|}{0.10} & \multicolumn{4}{|c|}{0.04} & \multicolumn{4}{|c|}{0.06} \\
\hline & \multicolumn{4}{|c|}{0.09} & \multicolumn{4}{|c|}{0.03} & \multicolumn{4}{|c|}{0.05} \\
\hline & \multicolumn{4}{|c|}{0.17} & \multicolumn{4}{|c|}{0.06} & \multicolumn{4}{|c|}{0.10} \\
\hline
\end{tabular}

See footnotes of Table 3 for treatment designations.

Considering foliar application of manure tea or amino acids, results showed pronounced increases in all photosynthetic pigments and the treatments receiving manure tea or amino acids surpassed the untreated ones in respect to the photosynthetic pigments. In this concern, the highest 
values of chlorophyll $\mathrm{a}, \mathrm{b}$ and carotenoids $(2.51,1.09$ and $1.34 \mathrm{mg} / \mathrm{g}$ fresh weight) were recorded by the treatment of $100 \% \mathrm{RDF}+\mathrm{CM}_{1}+$ amino acids. Ghobrial et al. (2009) stated that the increase in photosynthetic pigments formation could be due to the increase of nutrients content in plant as a result of foliar spraying by compost tea. The simulative effects of amino acids on plant pigments might be explained by the importance of polyamines for growth regulation, protein biosynthesis and retarding chlorophyll degradation. In this respect, Hanafy et al. (2010) found that foliar application of amino acids significantly increased chlorophyll $a, b$ and carotenoids concentration of snap bean leaves.

Nitrogen, $\mathrm{P}, \mathrm{K}$ and protein content in faba bean seeds:

Results in Table (6) showed significant increases in N, P and $K$ concentration as well as protein contents in faba bean seeds upon the sole or combined application of NPK fertilizers and chicken manure and the increase was progressive up to $100 \%$ RDF and /or $\mathrm{CM}_{2}$. Nitrogen, $\mathrm{P}, \mathrm{K}$ and protein contents increased by $26.6,26.9,54.3$ and $36.4 \%$, respectively due to the treatment of $100 \%$ RDF $+\mathrm{CM}_{2}$ over the control. Results show that when organic and mineral fertilizers were applied together, N, P and K content was higher than with organic or mineral fertilizers solely, and this may be explained on the basis that the combined addition of organic and NPKmineral maintains a continuous satisfactory increases in the efficiency of nutrient utilization and reduce nutrients losses. Mahmoud et al. (2006) reported that the mixing ratio $3: 1$ ( $\mathrm{N}$-mineral : $\mathrm{N}$-organic) was found to be superior in increasing $\mathrm{N}, \mathrm{P}$ and $\mathrm{K}$ uptake by wheat plants over the single application of any of the two fertilizers types. Almost similar results were obtained by Ayeni and Adetunji (2010) on maize. Foliar application of manure tea or amino acids had a significant effect on N, P, K and protein contents in faba bean seeds and treatments received manure tea or amino acids recorded higher values compared to the untreated ones and that occurred under the different applied rates of mineral fertilizers. In this respect, the highest values of $\mathrm{N}, \mathrm{P}, \mathrm{K}$ and protein contents $(3.82,23.9,0.63$ and $2.54 \%$, respectively) were produced by the treatment of $100 \%$ RDF + CM1 + amino acids. These results are in accordance with those obtained by El-Tantawy et al. (2009) on potato and Ghobrial et al. (2009) on faba bean, who noticed that sparing plants with manure tea caused pronounced increases in $\mathrm{N}, \mathrm{P}$ and $\mathrm{K}$ concentrations. Moreover, Eisa, Salwa (2011) pointed out that foliar spray of amino acids on peanut and sesame enhanced protein, $\mathrm{N}, \mathrm{P}$ and $\mathrm{K}$ contents in seeds.

Seed yield and yield components :

Data presented in Table (7) revealed that the addition of mineral fertilizers and /or chicken manure significantly augmented number of pods plant $^{-1}$, weight of 100 seeds and seed yield and the increases progressed with increasing their rates up to $100 \% \mathrm{RDF}$ and/or $\mathrm{CM}_{2}$. Integrated application of NPK fertilizers with chicken manure resulted in higher values of yield components compared to those values obtained when they added solely. 
Mahmoud, M. M.

6

1068 
In this concern, the relative increase of number of pods plant ${ }^{-1}$, weight of 100 seeds and seed yield due to the treatment of $100 \% \mathrm{RDF}+\mathrm{CM}_{2}$ were 46.2, 12.8 and $43.9 \%$ over the control. Integrated use of fertilizers and poultry manure exhibited the additive effect on groundnut pod yield in the treatment receiving full recommended dose of mineral fertilizer along with poultry manure at rate of 3 ton/ha (Talashilker et al., 1997). Furthermore, Suvarnalatha (2001) observed that the addition of chicken manure up to 6 ton/ha with $0,25,50$ and $100 \%$ RDF increased rice yield.

Table (7): Effect of chicken manure, manure tea, amino acids and NPK fertilizers on yield and yield components of faba bean.

\begin{tabular}{|c|c|c|c|c|c|c|c|c|c|c|c|c|}
\hline \multirow{3}{*}{$\begin{array}{l}\text { Treatments } \\
\text { (B) }\end{array}$} & \multicolumn{12}{|c|}{ (A) Fertilizer levels (\% recommended dose of NPK) } \\
\hline & \multicolumn{4}{|c|}{ No. of pods plant ${ }^{-1}$} & \multicolumn{4}{|c|}{$\begin{array}{c}\text { Weight of } 100 \text { seeds } \\
(\mathrm{g})\end{array}$} & \multicolumn{4}{|c|}{ Seed yield $(\mathrm{kg} / \mathrm{fed})$} \\
\hline & 35 & 65 & 100 & Mean & 35 & 65 & 100 & Mean & 35 & 65 & 100 & Mean \\
\hline Control & 26.0 & 30.0 & 33.3 & 29.8 & 91.3 & 94.8 & 98.0 & 94.7 & 862 & 997 & 1110 & 990 \\
\hline $\mathrm{CM}_{1}$ & 29.7 & 33.3 & 36.0 & 33.0 & 94.4 & 98.0 & 101 & 97.8 & 990 & 1103 & 1147 & 1080 \\
\hline $\mathrm{CM}_{2}$ & 33.0 & 35.7 & 38.0 & 35.6 & 97.0 & 100 & 103 & 100 & 1092 & 1180 & 1240 & 1171 \\
\hline Manure tea & 31.7 & 34.0 & 36.7 & 34.1 & 95.8 & 98.7 & 102 & 98.8 & 1072 & 1164 & 1220 & 1152 \\
\hline Amino acids & 32.0 & 35.0 & 37.3 & 34.8 & 96.2 & 100 & 103 & 99.7 & 1080 & 1172 & 1235 & 1156 \\
\hline Manure tea + $\mathrm{CM}_{1}$ & 34.7 & 37.3 & 40.0 & 37.3 & 100 & 104 & 106 & 103 & 1214 & 1276 & 1325 & 1272 \\
\hline Amino acids+ $\mathrm{CM}_{1}$ & 36.0 & 38.7 & 41.3 & 38.7 & 102 & 105 & 108 & 105 & 1233 & 1295 & 1350 & 1293 \\
\hline Mean & 31.9 & 34.9 & 37.5 & & 96.7 & 100 & 103 & & 1078 & 1170 & 1232 & \\
\hline \multirow{3}{*}{$\operatorname{LSD}_{0.05}$} & \multicolumn{4}{|c|}{2.14} & \multicolumn{4}{|c|}{2.60} & \multicolumn{4}{|c|}{49.7} \\
\hline & \multicolumn{4}{|c|}{2.03} & \multicolumn{4}{|c|}{2.34} & \multicolumn{4}{|c|}{46.2} \\
\hline & \multicolumn{4}{|c|}{3.81} & \multicolumn{4}{|c|}{ N.S } & \multicolumn{4}{|c|}{ N.S } \\
\hline
\end{tabular}

See footnotes of Table 3 for treatment designations.

Regarding foliar application of manure tea and amino acids, results indicated that foliar spray of manure tea and amino acids had a significant positive effect on pod plant ${ }^{-1}$, weight of 100 seeds and seed yield, the treatments receiving manure tea or amino acids surpassed the untreated ones and such positive effect holds true under the different rates of NPK fertilizers. The obtained values as a result of application of manure tea or amino acids (irrespective of mineral or organic fertilizers) did not differ significantly in their effects on yield and yield components. In spite of the treatment of full dose of NPK along with $\mathrm{CM}_{1}+$ manure tea or amino acids produced the greatest yield, the application of $65 \%$ NPK with manure tea or amino acids showed superiority over the treatment with the single application of $100 \%$ NPK, indicating that the need for NPK fertilizers can be reduced to $65 \%$ compared to $100 \%$ RDF and saving $35 \%$ NPK fertilizers. These findings are in accordance with those reported by Meshref et al. (2010) who stated that spraying compost tea on plants significantly increased kidney bean crop and reduce the need of mineral fertilizers. The positive effect of amino acids on growth and yield may be due to improving the original ultra structure in the cell especially the plastids in mesophyll tissue which improving photosynthetic efficiency leading to production of more assimilates needed for formation of new cell reflected to increase plant height, leaf area, tillers as well as yield and its components. Moreover, amino acids stimulate the activity of some enzemes responsible protein and carbohydrates 
synthesis and therefore biomass and this action is directly correlated with the yields. These results are partially in line with those reported by El-Ghamry et al. (2009) on faba bean, Hanafy et al. (2010) on snap bean and Fawzy et al. (2010) on snap bean

\section{Conclusion}

From the above mentioned results it could be concluded that the integrated application of manure tea or amino acids with mineral and organic fertilizers could reduce the crop requirements for the two types of fertilizers. This indicates the beneficial effect of integrated nutrients approach with manure tea and amino acids to increase crop yields by supplementing all nutrients readily to crop. Moreover, such manure or composting extracts are also likely to be useful in low input agricultural systems in developing countries, where chemicals are either too expensive for small farmers to buy or commercially unobtainable.

\section{REFERENCES}

Ayeni, L.S. and M. T. Adetunji (2010). Integrated application of poultry manure and mineral fertilizer on soil chemical properties, nutrient uptake, yield and growth components of maiz. Nature and science, 8 (1) : $60-67$.

Bidwell, R.G.S.(1980). Plant Physiology. 2 nd Ed., Callier Mac Millan Publisher, London, New York.

Black, C.A. (1965). Methods of Soil Analysis. Amer. Soc. of Agronomy, Inc. Pub., Madison, Wisconsin, U.S.A.

Choudhry, A. N.; G. Jilani ; M. A. Khan and T. Iqbal (2009). Improved processing of poultry litter to reduce nitrate leaching and enhance its fertilizer quality. Asian J. Chem., $21: 4997-5003$

Chettri, M. and P. Bandhopadhaya (2005). Effect of integrated nutrient on fertilizer use efficiency and changes in soil-fertility status under rice (Oryza stiva) based cropping system. Indian J. of Agric. Sci., 75 (9): $596-599$.

Duncan, J. (2005). Composting chicken manure. WSU Cooperative Extesion, King County Master Gardener and Cooperative Extension Livestock Advisor.

Eid,Rawia, , S. A.; Abo-Sedera and M. Attia (2006). Influence of nitrogen fixing bacteria incorporation with organic and/or inorganic nitrogen fertilizers on growth, flower yield and chemical composition of Celosia argentea. Word J. of Agric. Sci., 2 (4): 450 - 458.

Eisa.Salwa, A. I. (2011). Effect of amendments, humic and amino acids on increases soils fertility, yields and seed quality of peanut and sesame on sandy soils. Res. J. of Agric. and Biolog. Sci. 7 (1) : $115-125$.

El-Ghamry, A. M. (2011). Soil fertility and potato production as affected by conventional and organic farming systems. J. Soil Sci. and Agric. Eng., Mansoura Univ., 2 (2): $141-156$. 
El-Ghamry, A.M.; Kamar M. Abd El-Hadi and K.M. Ghoneem (2009). Amino and humic acids promote growth, yield and disease resistance of faba bean cultivated in clayey soil. Aust. J. of Basic Appl. Sci., 3(2): 731739.

El-Tantawy, I. M.; A. M. El-Ghamry and A. H. Habib (2009). Effect of chicken manure and manure compost tea on potato yield and soil fertility. $\mathrm{J}$. Agric. Sci. Mansoura Univ., 34 (1) : $659-668$.

Fawzy, Z. F.; A. M. El-Bassiony; AG. Behairy and Y. I. Helmy (2010). Effect of foliar spraying by some bio and organic compound on growth, yield and chemical composition of snap bean plants. J. of Appl. Sci. Res., 6 (12): $2269-2274$.

Ghobrial, W. N.; Ahlam A. Mehesen and Jehan M. Abbas (2009). Potential impacts of Rhizobium and compost tea enriched with rhizobacteria for enhancing protection of faba bean against broad bean mottle virus (BBMV). J. Agric. Res. Kafer El-Sheikh Univ., $35: 1-25$.

Gomaa, A. M.; M. H. M. Afifi; Manal F. Mohamed and Kamilia Y. Dewiny (2010). Nodulation, growth parameters and yield quality of faba bean cultivated in a newly reclaimed sandy soil under bio - organic agriculture system. International J. of Academic Res., 2 (5): 134 -138.

Gomez , K.A. and A.Gomez (1984). Statistical procedures for agricultural research, $\left(2^{\text {nd }}\right.$ ed.) pp: 20-29 \& 359-387.

Haggag, W. M. and M. S. M. Saber (2007). Suppression of early blight on tomato and purple blight on onion by foliar sprays of aerated and non - aerated compost tea. J. of food, Agric \& Envir. 5 : $302-309$.

Hanafy, A. A. H.; M. R. Nesiem; A. M. Hewedy and H. S. Sallam (2010). Effect of some simulative compounds on growth, yield and chemical composition of snap bean plants grown under calcareous soil conditions. J. of American Sci., 6 (10): 552 - 569.

Hiber, K.; M. Daami - Remadi; H. Jabnon - Khiareddine; I. E. Znaidi and M. El-Mhjoub (2006). Effect of compost tea on mycelial growth and disease severity of fusarium oxysporum f. sp. radicis. lycopersici. Biotechnology, Agronomy, society, and Environment. $10: 101-108$.

Ibrahim, M. E.; M. A. Bekheta, A. El-Moursi and N. A. Gafar (2007). Improvement of growth and seed yield quality of vicia faba L. plants as affected by application of some bioregulators. Aust. J. Basic and Appl. Sci., 1 (4): $657-666$.

Jackson, M.L. (1973). Soil Chemical Analysis. Prentice Hall of India Private Limited, New Delhi, India.

Lipson, D. A. and T. Nasholm (2001). The unexpected versatility of plants: organic nitrogen use and availability in terrestrial ecosystems. Oecologia, 128: $305-316$.

Mahmoud, M. M.; Gehan H. Youssef and Wafaa M. A. Saddik (2006). Partial replacement of $\mathrm{N}$ - mineral requirements by $\mathrm{N}$ - organic source as related to both sesame - wheat yields and their components (2006). Egypt. J. of Appl. Sci., 21 (6 B): 781 - 792. 
Meshref, H. A.; M. H. Rabie; A. M. El-Gamry and M. A. El-Agamy (2010). Maximizing utilization of compost addition using foliar compost extract and humic substances in alluvial soil. J. Soil and Agric. Eng., Mansoura Univ., 1(9): $957-971$.

Sharma, N and V. K. Rao (1996). Poultry byproducts and their utilization. Indian Farming, 46 (6) : $15-18$.

Sheuerell, S. and W. Mahaffee (2002). Compost tea: Principles and prospects for plant disease control. Compost Sci. and Utilization, 10 (4): $313-318$.

Suvarnalatha, A. J. (2001). Integrated use of fertilizer and poultry manure in nutrient availability and yield of rice. Abstract of M. Sc. (Agri) Thesis. J. of Res. Angrau, 32 (3): 126.

Taiz, L. and E. Zeiger (1998). Plant physiology. 2 nd Ed. Sinauer, Sunserland, Mass.

Talashilkar, S. C.; A. A. K. Dosani; Mehta and A. G. Power (1997). Integrated use of fertilizers and poultry manure to groundnut crop. J. of Maharashtra Agricultural universities, 22 (2): $205-207$.

Waller, G. R. and E. K. Nowaki (1978). Alkaloid, biology and metabolism in plants. Plenum Press, New York, 85 - 247.

Wettestein, D.(1957). Chlorophyll, lated und der Submikrosvopishe Fommech Sell-der-plastiden. Exptal.Cell Res.,12:427-433.

Willrich. T.L. ; D.O. Turner and V.V. Volk (1974). Manure application guidelines for Pacific Northwest . ASAE paper No. 74-4601. American Society of Agricultural J. 83: 729-732.

Zhang, Q.Y.; Y.Chen ; G. Jilani ; I.H. Shamsi and Q.Yu (2010). Model Avswat Apropos of simulating non - point source pollution in Taihu lake basin. J. Haz. Mat, 174: 824-830.

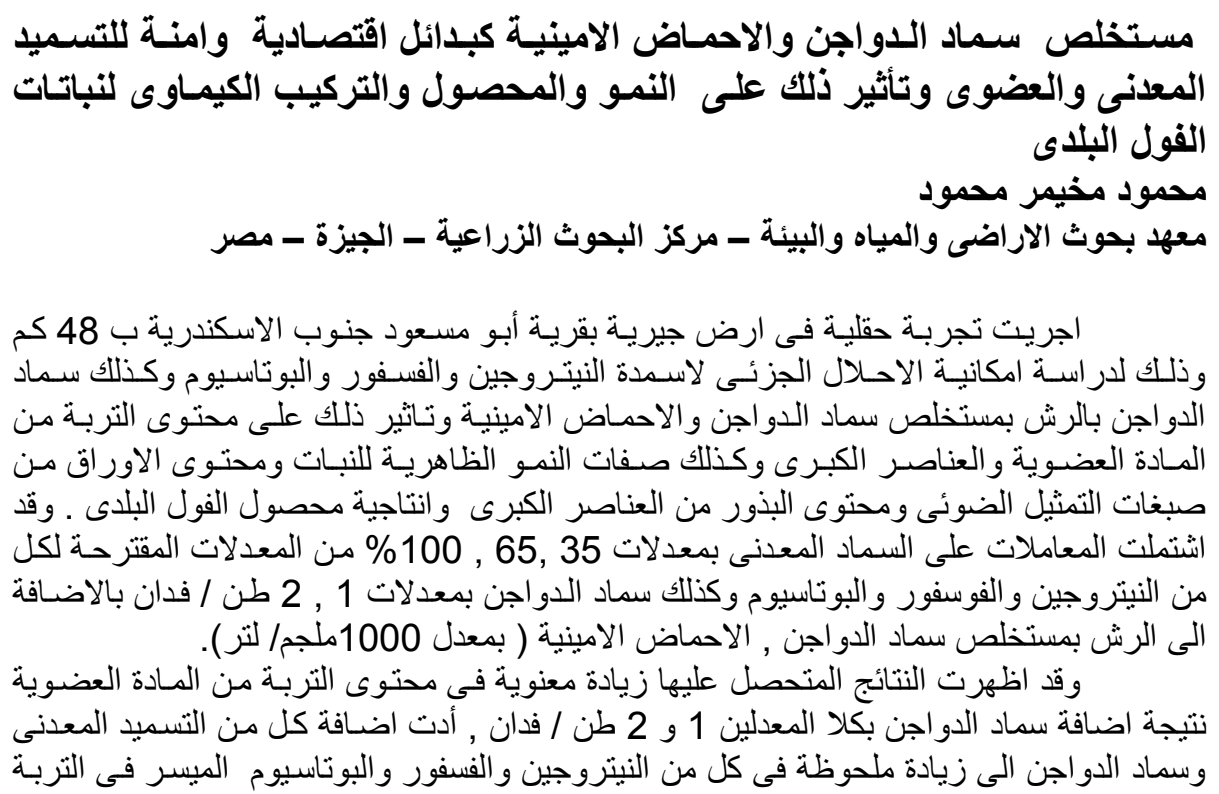


وكانت الافضلية للمعاملة 100\% من المعدلات الموصى بها للتسميد + 2 طن سماد دواجن / فدان

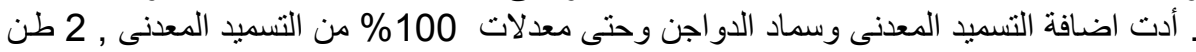

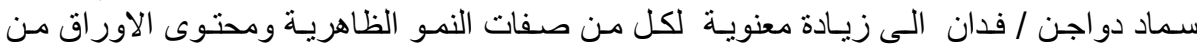

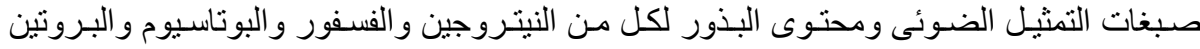

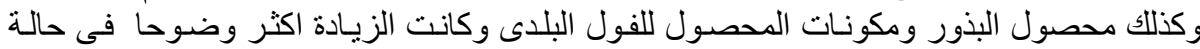

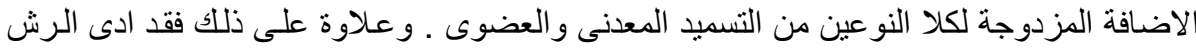

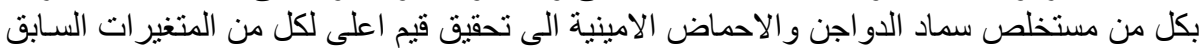

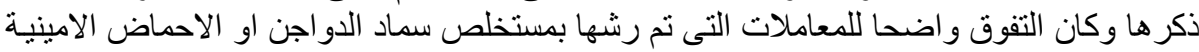

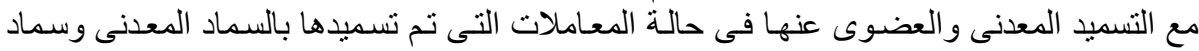

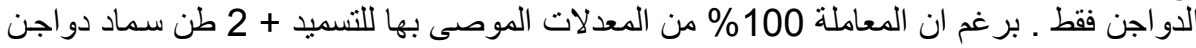

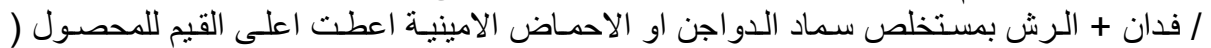

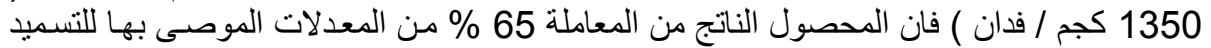

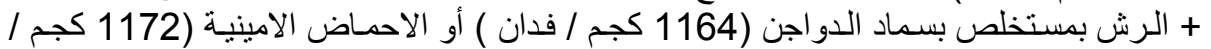

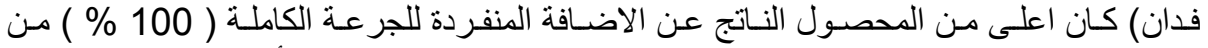

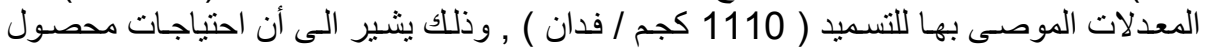

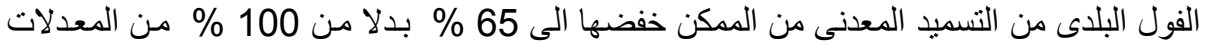
المقترحة للتسميد المعنى وذللك من الممكن أن يو فر 35 \% من التسميد المعدنى .

كلية الزراعة - جامعة المنصورة مركز البحوث الزراعية
قام بتحكيم البحث

أ.د / محمد يحيى سيد البحث العرقان

أ.د / محمود حنفى محمود 
J.Soil Sci. and Agric. Eng., Mansoura Univ., Vol. 2 (10): 1059 - 1073, 2011

Table (3): Effect of chicken manure, manure tea, amino acids and NPK fertilizers on organic matter and available macronutrients.

\begin{tabular}{|c|c|c|c|c|c|c|c|c|c|c|c|c|c|c|c|c|}
\hline \multirow{3}{*}{\begin{tabular}{|l} 
Treatments \\
(B)
\end{tabular}} & \multicolumn{16}{|c|}{ (A) Fertilizer levels (\% recommended dose of NPK) } \\
\hline & \multicolumn{4}{|c|}{ Organic matter $(\%)$} & \multicolumn{4}{|c|}{ Available N } & \multicolumn{4}{|c|}{ Available $\mathbf{P}$} & \multicolumn{4}{|c|}{ Available K } \\
\hline & 35 & 65 & 100 & Mean & 35 & 65 & 100 & Mean & 35 & 65 & 100 & Mean & 35 & 65 & 100 & Mean \\
\hline Control & 1.02 & 1.04 & 1.04 & 1.03 & 66.1 & 72.0 & 76.9 & 71.7 & 11.3 & 12.8 & 13.9 & 12.7 & 285 & 310 & 332 & 309 \\
\hline $\mathrm{CM}_{1}$ & 1.14 & 1.15 & 1.17 & 1.15 & 71.4 & 78.7 & 85.4 & 78.5 & 12.8 & 14.2 & 15.2 & 14.1 & 316 & 345 & 368 & 343 \\
\hline $\mathrm{CM}_{2}$ & 1.24 & 1.26 & 1.27 & 1.26 & 76.6 & 85.0 & 93.5 & 85.0 & 13.9 & 15.2 & 16.1 & 15.1 & 342 & 372 & 398 & 371 \\
\hline Manure tea & 1.03 & 1.05 & 1.06 & 1.05 & 65.8 & 70.9 & 76.7 & 71.1 & 11.3 & 12.7 & 14.0 & 12.7 & 280 & 310 & 326 & 305 \\
\hline Amino acids & 1.04 & 1.06 & 1.06 & 1.05 & 65.5 & 71.1 & 76.3 & 71.0 & 11.1 & 12.6 & 14.2 & 12.6 & 277 & 305 & 330 & 304 \\
\hline Manure tea + $\mathrm{CM}_{1}$ & 1.16 & 1.16 & 1.18 & 1.17 & 70.8 & 78.3 & 84.6 & 77.8 & 12.7 & 13.9 & 15.0 & 13.9 & 311 & 335 & 362 & 336 \\
\hline Amino acids $+\mathrm{CM}_{1}$ & 1.17 & 1.16 & 1.17 & 1.17 & 70.5 & 78.1 & 85.0 & 77.9 & 12.9 & 14.0 & 14.8 & 13.9 & 314 & 342 & 358 & 338 \\
\hline Mean & 1.11 & 1.13 & 1.14 & & 69.5 & 76.3 & 82.6 & & 12.3 & 13.6 & 14.6 & & 303 & 330 & 353 & \\
\hline \multirow{3}{*}{$\mathrm{LSD}_{0.05}$} & \multicolumn{4}{|c|}{ N.S } & \multicolumn{4}{|c|}{5.16} & \multicolumn{4}{|c|}{0.80} & \multicolumn{4}{|c|}{20.1} \\
\hline & \multicolumn{4}{|c|}{0.08} & \multicolumn{4}{|c|}{5.10} & \multicolumn{4}{|c|}{0.73} & \multicolumn{4}{|c|}{17.5} \\
\hline & \multicolumn{4}{|c|}{ N.S } & \multicolumn{4}{|c|}{ N.S } & \multicolumn{4}{|c|}{ N.S } & \multicolumn{4}{|c|}{ N.S } \\
\hline
\end{tabular}

$\mathrm{CM}_{1}$ : Chicken manure at rate of 1 ton/fed

$\mathrm{CM}_{2}$ : Chicken manure at rate of 2 ton/fed 
J. Soil Sci. and Agric. Eng., Mansoura Univ., Vol. 2 (10), October, 2011

Table (6): Effect of chicken manure, manure tea, amino acids and NPK fertilizers on macronutrients and protein content in faba been seeds.

\begin{tabular}{|c|c|c|c|c|c|c|c|c|c|c|c|c|c|c|c|c|}
\hline \multirow{3}{*}{\begin{tabular}{|l} 
Treatments \\
(B)
\end{tabular}} & \multicolumn{16}{|c|}{ (A) Fertilizer levels (\% recommended dose of NPK) } \\
\hline & \multicolumn{4}{|c|}{ N (\%) } & \multicolumn{4}{|c|}{ Protein (\%) } & \multicolumn{4}{|c|}{$\mathbf{P}(\%)$} & \multicolumn{4}{|c|}{ K (\%) } \\
\hline & 35 & 65 & 100 & Mean & 35 & 65 & 100 & Mean & 35 & 65 & 100 & Mean & 35 & 65 & 100 & Mean \\
\hline Control & 2.74 & 2.97 & 3.16 & 2.96 & 17.1 & 18.6 & 19.8 & 18.5 & 0.35 & 0.40 & 0.46 & 0.40 & 1.62 & 1.81 & 1.97 & 1.80 \\
\hline $\mathrm{CM}_{1}$ & 2.93 & 3.12 & 3.32 & 3.12 & 18.3 & 19.5 & 20.8 & 19.5 & 0.40 & 0.46 & 0.50 & 0.45 & 1.74 & 1.94 & 2.10 & 1.93 \\
\hline $\mathrm{CM}_{2}$ & 3.10 & 3.33 & 3.47 & 3.30 & 18.8 & 20.8 & 21.7 & 20.4 & 0.44 & 0.49 & 0.54 & 0.49 & 1.85 & 2.04 & 2.21 & 2.03 \\
\hline Manure tea & 3.15 & 3.36 & 3.51 & 3.34 & 19.7 & 21.0 & 21.9 & 20.9 & 0.45 & 0.50 & 0.54 & 0.50 & 1.88 & 2.08 & 2.24 & 2.07 \\
\hline Amino acids & 3.24 & 3.41 & 3.59 & 3.41 & 20.3 & 21.3 & 22.4 & 21.3 & 0.48 & 0.52 & 0.56 & 0.52 & 1.95 & 2.15 & 2.30 & 2.13 \\
\hline Manure tea + $\mathrm{CM}_{1}$ & 3.35 & 3.54 & 3.68 & 3.52 & 20.9 & 22.1 & 23.0 & 22.0 & 0.51 & 0.56 & 0.59 & 0.55 & 2.13 & 2.27 & 2.38 & 2.26 \\
\hline Amino acids $+\mathrm{CM}_{1}$ & 3.41 & 3.63 & 3.82 & 3.62 & 21.3 & 22.7 & 23.9 & 22.6 & 0.54 & 0.60 & 0.63 & 0.59 & 2.25 & 2.40 & 2.54 & 2.40 \\
\hline Mean & 3.13 & 3.34 & 3.51 & & 19.5 & 20.9 & 21.9 & & 0.45 & 0.50 & 0.55 & & 1.92 & 2.10 & 2.25 & \\
\hline \multirow{3}{*}{ LSD $_{0.05}$} & \multicolumn{4}{|c|}{0.14} & \multicolumn{4}{|c|}{0.68} & \multicolumn{4}{|c|}{0.03} & \multicolumn{4}{|c|}{0.11} \\
\hline & \multicolumn{4}{|c|}{0.12} & \multicolumn{4}{|c|}{0.62} & \multicolumn{4}{|c|}{0.02} & \multicolumn{4}{|c|}{0.10} \\
\hline & \multicolumn{4}{|c|}{0.23} & \multicolumn{4}{|c|}{1.09} & \multicolumn{4}{|c|}{ N.S } & \multicolumn{4}{|c|}{0.20} \\
\hline
\end{tabular}

See footnotes of Table 3 for treatment designations 
Mahmoud, M. M.

1076 